\title{
'A Song in Search of a Voice that is Silent': Feminist Readings of When She Hollers and Touching Earth Lightly
}

\author{
Anna Beth McCormack
}

\begin{abstract}
The silence
Arguably, the subject most silent in literature for children and young adults is sexual abuse- particularly incest. And when it is mentioned, it is likely to be treated softly (examples being The Year of Freaking Out by Sarah Walker and The Tulip Touch by Anne Fine). Sexual abuse is arguably the subject that should be loudest in literature for children and young adults. as it affects perhaps a third of all girls and some fewer boys, and their children, and is destructive to the point of death. (See the Data appendix.) Yet for sexually abused children, their song is largely silent.
\end{abstract}

Into this near-void fit the two young adult novels When She Hollers by Cynthia Voigt (1994) and Touching Earth Lightly by Margo Lanagan (1996). Both are by notable female writers for young adults. Both are tough stuff. Touching Earth Lightly is still available, but When She Hollers has been out of print since 1996, despite the renown and general 'in print' status of its author. Neither has been followed by a spate of similar books, despite the fact that the 1990s saw a plethora of young adult fiction dealing with grim social issues. The scarcity of books on this subject may be due to market censorship-that is, to a combination of negative decisions made by individual authors, publishers and gatekeepers (particularly educationalists and librarians) about what will or won't be acceptable, or should or should not be offered to young people. However, as I will suggest, the scarcity may also be due to inherent difficulties in writing on the subjectdifficulties arising partly from the need to get the feminist mix "right".

Feminist, female and feminine

Some clarification of terms is needed here. Following Moi (1997). I take 'feminist' as a political/economic/ legal term which refers to the rights of women as peopleparticularly, here, to girls' rights to safety, help and legal redress. 'Female' is a biological term and refers to sexuality, including motherhood. 'Feminine' refers to learned social behaviour and attitudes-particularly, here, to passivity under sexual abuse.

\begin{abstract}
Structure and point of view
When She Hollers and Touching Earth Lightly both centre on teenage girls who have long been incestuously abused. However, the authors' approaches to the situation and resolutions differ markedly. In When She Hollers, Tish (aged 16-17) has been sexually abused by her stepfather-cum-adopted father (Tonnie) since infancy. Her mother conspires with him by willfully not seeing the situation. The book's action takes place within one day, as Tish finally challenges her situation. Her rebellion is triggered by the suicide of another girl, Miranda, who (Tish believes) was in a similar situation. The story is chronological and linear, climaxes in the last few pages and does not close. The point of view-the voice-is always intimately 'Tish's. This structure and point of view keep Tish's story foregrounded and strong.
\end{abstract}

In Touching Earth Lightly, Janey (aged 17-18) has been the victim of both her father and brother since adolescence. She has been rejected by her mother and herself has a baby son whom she gave up for adoption at birth. Janey is always seen from the viewpoint of Chloe, Janey's friend since age 12. The book is structured as Chloe's story. The first half of the book ('Now') is about Chloe's relationship with Janey during the few months after the birth, as Chloe tries to keep Janey safe from her brother and father. Then Janey is murdered by two teenagers. The second half ('Then') covers the few months after the murder during which Chloe collects Janey memorabilia for Janey's son, grieves, and assesses her own role in Janey's life, which is seen in flashbacks. The story closes with Chloe establishing a romantic relationship to carry her safely into the future. The effect of this structure and viewpoint is to split the reader's focus between Janey and Chloe, to silence Janey's voice and distance Janey from the reader, and hence to soften the impact of Janey's story, even as it is toid.

Although both books are by female writers and deal with feminist issues, When She Hollers is more logocentric and 'masculine' in structure and plot than Touching Earth Lightly' (Barry 1995, 126). The latter cannot be 
described as 'feminine writing' in Cixous's terms (1997, p.127), but in its diffusion is what Nodelman (1988, p.33) might call 'feminine literature'.

\section{Blaming the victim}

For both books, the archetypal fairy tale is, of course, 'Little Red Riding Hood', which has been collected and discussed in depth by Zipes (1983). Touching Earth Lightly' is closest to the Perrault version, where a passive but sexy Little Red Riding Hood is eaten up in good patriarchal blame-the-victim tradition:

... the moral tells us that young girls ... must exercise control over their sexual and natural drives or else they will be devoured by their own sexuality in the form of a dangerous wolf. (Zipes 1991, p.24)

When She Hollers is closer to the Grimms' version. At first it seems to be heading towards an aggressive feminist parody, with 'Tish carrying a 'survival knife' in her Docs, much like Roald Dahl's 'small girl' who 'whips a pistol from her knickers' and converts the wolf to a 'lovely furry wolfskin coat' (Dahl 1984, p.27). But Voigt provides a fortuitous hunter in the form of a male lawyer named Battle, who persuades Tish to write down the truth.

Both books differ significantly from the fairy tale in that the Wolf is resident within the family and has multiple powers, so does not need to trick or seduce. Common sense suggests that this power imbalance would exonerate Little Red Riding Hood from blame, but not so. In When She Hollers, Tonnie and Tish's mother both try to lay responsibility on Tish, playing a mind-twisting game that has kept Tish compliant over many years. At school, Tish's friends follow the feminine line in discussing the dead Miranda. They are content to blame Miranda for her pregnancy and suicide, till disturbed in this view by Tish's questions. In Touching Earth Lightly, Janey accepts her adolescent sexuality as the reason for her father and brother's sexual interest and her mother's rejection. She also accepts her female 'cycle' as responsible for her profligate sexual activities, which lead directly to her murder by a pair of young wolves.

\section{Feminism compromised}

In many ways, When She Hollers seems to be intended as a DIY manual for sexually abused girls and an information booklet for their friends. Options are presented, with wamings about their outcomes. However, in presenting these options the book also ratifies the patriarchal society, because good outcomes seem very difficult to win. Tish's key obstacle is silence. She has always been silenced, by Tonnie's combination of threats and mind-twisting. Each time she tries to 'holler', she is silenced again: by her mother, schoolmates. teacher and principal. Even Battle abrogates the voice that he should raise in accordance with child protection laws, when he gives Tish the option of official silence, an option which Tish temporarily accepts. (However, this action can be construed two ways: as a contra-feminist failure to protect Tish, or as a feminist devolution of control to Tish.) The book ends with Tish about to confront Tonnie, despite the door 'bulging out with all the fury behind it' (p.173):

\section{Now, no matter what happened to Tish, Tonnie wouldn't get away. Even if he got her before she made up her heart to bring charges. And tell the police. \\ Because she knew she was going to do that. Sooner or later. \\ Tish knew it was up to her. She was the only one who could do this first thing, and everything after. She was the one who would have to. (pp.174-5)}

Tish chooses to perform the Grimms sequel to Little Red Riding Hood alone. But just how smart is it to walk back into the woods knowing the Wolf is there? Feminism is asserted but in jeopardy: it fails if she lets Battle fight her battle for her, and also if she battles alone but loses. In this High Noon situation Tish's chances seem slim. This ending quite possibly comes from Voigt's wishing to end the book positively but not neatly, for in reality the outcome is always messy-and incomplete.

In Touching Earth Lightly, the feminist position is undercut more clearly. Chloe stands in counterpoint to 
Jancy as ice to fire. Since they met as 12 -year-olds. Chloe has lived vicariously through Janey, feeding off her colour, emotion and creativity. Regardless of disapproval, Chloe becomes Janey's shadow, telling herself she is looking atter Janey. She accompanies Janey on sexual forays into dark Dantean places inhabited by 'rat boys', to stand watch. 'Frigid', they call her. Chloe's ou'n first affair is lukewarm, punctuated by midnight excursions to mind Janey. Her job as an opera walk-on playing an 'Ice Princess' is to sit unmoving on a high throne while grand passion swells around her. Her job symbolises her life. After Janey's murder. Chloe realises that she has failed Janey when most needed, for no worth while reason. Both Chloe and her parents also realise that they have failed Janey through their policy of non-intervention. They breast-heat but excuse themselves, for the alternative is too painful to contemplate:

'Okay / says Joy], I won't go on. I just feel as if coervone is guilty' of this. Catshing and trying those stupid kids is just our easiest way out. They're just ... I don't know, our agents, somehow.

'That's ridiculous, ' murmurs Dane. 'As if we wanted them to do that.'

(p.182)

The uncomfortable sense arising from this passage is that Dane's words may be accurate, for the death of aggressively femaie Janey restores their world to cool masculine order. When Janey's memory needs no further attention, Chloe finds a romantic relationship with the long-time friend of her brother. However, for Chloe the Ice Princess this new relationship does not seem to he passion unleashed, so much as falling painlessly into a safe corner.

When the story is donc, what has happened? All the gender-based mores of a patriarchal society have been upheld. Female sexuality has been punished; errant male sexuality has been tolerated; sncial blinkers have been wom: female inhibition has been rewarded. Something seems $(0)$ have gone very urong. Feminism is supported only by Janey"s negative example-a tacit injunction to the reacler not to be like her. Chloe's inhibition, being rewarded, is a feminist disincentive. In Stephens's words: 'A text may overtly advocate one ideology while implicitly inscribing one or more other ideologies.' (1992, p.43).

\section{Diversions}

In Touching Earth Lightly, other social mores are upheld also. Chloe's family are all 'nice' people, intelligent. educated, well-off. By contrast, Janey's family are working-class dregs living in squalor. Hence the reader is diverted into a socioeconomic furphy about a feminist issue. The unthinkable reality that such bad things can happen in 'nice' families is avoided. When She Hollers avoids this socioeconomic furphy. Tish's family is middle American. However, Voigt, like Lanagan, also dissociates her story from unthinkable reality: Tonnie is Tish's stepfather/adopted father, not her 'real' father. Just as the real mother in fairy tales is often represented by a 'stepmother', so Tonnie must be a stepfather because 'real' fathers don't do that.

\section{Closures}

Whether and how a book closes affects interpretation of the text's ideological meaning, but closure is not fixed. To quote Stephens,

The degree of openness in the ending depends on the nature and cxtent of the instabilities represented in the text and on the extent to which they are resolved, but readers may nevertheless impose closure.

(Stephens 1992, p. 42)

Some readers may interpret When She Hollers as closed, even though the immediate outcome is uncertain, because Tish is actively claiming her rights. Other readers, however, may interpret it as open, for whatever the outcome with Tonnie and at law. Tish still needs to fight a complex personal battic. We have already seen one part of this battle: that to save her mind (if not her body or freedom). Tish must cease to be passively feminine and actually do something, and do it herself. The longer-term and more difficult part is that, so long as she is reacting to Tonnie's abuse, she is subject to male dominance as much as when she was passively accepting his abuse. So long as she is even listressed by the memory of the abuse. 
she is a victim. Voigt does not address this need openlyit can be difficult to comprehend, let alone write, and would require a novel in itself-but the ambivalent closure suggests authorial recognition of the long-term consequences of sexual abuse for its victims. Closure in Touching Earth Lightly is much simpler: Janey dies; Chloc signs off her involvement with Janey and looks to her own future. Male/female, masculine/feminine, are in their proper places as winners and losers respectively; the social order is confirmed.

We can perhaps understand the closures if we relate them to the binary oppositions presented by Cixous (1997, p.91): activity/passivity, sun/moon, culture/nature, day/ night, head/heart, logos/pathos, man/woman: Tish/Janey. Janey never escapes from the feminine pole. Tish moves to the masculine pole, but must be at odds with herself so long as she stays there. But there is hope. Cixous says:

As for passivity, in excess, it is partly bound up with death. But there is a nonclosure that is not submission but confidence and comprehension; that is not an opportunity for destruction but for w'onderful expansion.

(1997, p.95)

This 'nonclosure' is not explained, but may correspond io Cixous's 'bisexuality' (p.93) or Dworkin's 'androgyny' (1974: 174ff.)

Feminine ambiguity, female repression

Voigt gives Tish the opportunity to use masculine weapons (the knife, the law) to turn and fight a feminist battle. In contrast, Lanagan gives Janey no such option. Janey is always on the run-literally in her search for safe accommodation, psychologically in her acceptance of 'blame' and translation of it into extravagant sexuality and bizarre behaviour. Her extremes, though disguised as aggressive individuality, are defences: they conceal her vulnerable self from both the world and herself. She is always reactive to her abuse, so she remains a victim. Her position is passive, feminine (though lacking any resemblance to conventional demure 'femininity'). In the end, her defence is broken when she is located and raped by her brother. Vulnerable again, she refuses the help of a rape crisis centre, goes it alone and is killed.
Tish also adopts defensive disguise: a different persona every day, so that no one will know who she really is. Her sexual disguise is the boyfriend who avoids personal invol vement; again, this shows reactive sexual behaviour. The really constructive action towards a solution starts when Tish blows her defence by screaming in the gym at school. With this irruption her true self begins to reveal itself to others. For Miranda, lacking defences, passivity leads to death-and to blame by Tish's mother (though it could be argued that choosing death is active, not passive). The schoolgirls twittering in Tish's lunchroom, condemning the overtly female (because pregnant) Miranda, are safe in a femininity that has not been pressed too hard. They can afford to hold the attitudes of the patriarchal society.

Tish's femaleness is suppressed; at home it is turned against her by Tonnie and her mother. Miranda's femaleness is punished by blame and its ultimate expression (maternity) by death. Janey's femaleness is exaggerated and used against her to 'blame the victim'. Her body is generously figured to reflect her mind. By making Janey so female, Lanagan leaves gaping the question of whether sexual abuse may generate problematic sexual behaviour in the abused-that is, whether Janey's uncontrolied femaleness is a cause or an effect. Lanagan's failure to address this age-old question tacitly supports the equally age-old patriarchal position that uncontrolled female sexuality is a 'cause' and therefore punishable. (Think back to 'Little Red Riding Hood'.) One punishment for Janey, and Miranda, is to disallow maternity. Chloe's femaleness, by comparison, is very subdued, so she is allowed to 'live happily ever after' with a suitably restrained and gentle lover. Her 'minding' Janey and making room for Janey's baby can be seen as sublimated and vicarious maternity. Tish's mother is the most approved feminine-female combination in the two books, because her sexuality and maternity (four children, and pregnant) are well under Tonnie's control.

The messages? Feminine passivity can be dangerous Femaleness must fit the bounds of the patriarchal society. Femaleness that challenges feminine passivity is to be suppressed. 


\section{Mothers and daughters}

All four mothers in the books show feminine passivity, not jus1 Tish's mother. and their influence is apparent in all four daughters. Agee discusses how parents, particularly mothers, influence 'female gender socialization' (p.167), saying:

The persistent psychological and sociological differences between male and female acculturation seem to begin early in life through parental expectations of daughters' roles in life. (1993, p. 166)

The truth of this is more evident in Touching Earth Lightly than in When She Hollers. Tish's mother actively tries to twist Tish's mind to Tonnie's will. Miranda's mother was an invalid, then died. Janey's mother is a model of subjugation to Janey's father. Chloe's parents are light-handed with Chloe to the point of detachment, and so is Chloe with Janey. Only Tish chooses to defy her socialisation and break the chain.

Andrea Dworkin, though actually writing about Chinese foot-binding, describes how mothers may be cruel to their daughters because of the abusive gender socialisation to which they themselves were subject. Part of her discussion reads:

The daughter who rejects the cultural norms enforced by the mother is forced to a basic rejection of her own mother, a recognition of the hatred and resentment she fel tow'ard that mother, an alienation from mother and society so extreme that her own womanhood is denied by both. The daughter who internalizes these values and endorses those same processes is bound to repeat the teaching she was taught-her anger and rescntment remain subterranean, channcled against her own female offspring as well as her mother.

(1974, p. 115)

Foot-binding, mind-binding. Is there much difference?

\section{Ideological difficulties}

Hollindale describes three main ways in which ideology is present in a children's book:

\begin{abstract}
... the explicit social, political or moral beliefs of the individual writer, and his wish to recommend them to children through the story... the individual writer's unexamined assumptions ... As a rule, writers for children are transmitters not of themsehes uniquely, but of the worlds they share. (Hollindale 1988, p. 27-33)
\end{abstract}

We can safely assume that both Voigt and Lanagan wished to give a voice to teenage girls who have suffered sexual abuse, particularly at home (Hollindale's first item). We can probably assume also that the reader is expected to carry away from When She Hollers both information and the inspiration 'yes, you can help yourself' (if you're a victim); and from Touching Earth Lightly both a sense of horror and an injunction to either 'stop running and deal with it' (if you're a victim) or 'really help' (if you're a friend).

The feminist difficulties of the two books may derive from the second and third ways which Hollindale says authors construct ideology in writing for children: the unexamined assumptions of writers; and the cultural givens, the 'worlds' which inform their writing. In the (at least partial) endorsement of the patriarchal society in both books. one can sense an acknowledgement that childhood sexual abuse is too difficult a problem for novels to resolve. There may even be an unconscious sense that the problem is too entrenched and hidden to change in reality. If the latter, one wonders how far this attitude may be rooted in the authors' own feminine socialization, remembering that before the 1980 s a general silence surrounded the topic of sexual abuse.

'A way of writing it'

The difficulty of writing on childhood sexual abuse was expressed to me recently by Morris Gleizman (2001). Asked whether there was any social issue so horrible that he wouldn't write about it, he said 'No', then added that he thought there should be a book on sexual abuse of children, but he couldn't write it. He didn't have 'a way of writing it'.

Such lack of 'a way of writing it' accords with the feminist difficulties found in this study of When She Hollers and Touching Earth Lightly, and it probably goes 
far to explain the scarcity of literature on sexual abuse for children and young adults-and the silence of the song.

\section{REFERENCES}

Agee, Jane M. (1993) 'Mothers and daughters: gender-role socialization in two Newbery Award books', Children's Literature in Elucation 24, 3: 165-183.

Barry, Peter (1995) Beginning theory: An Introduction to Literary and Cultural Theory. Manchester and New York, Manchester University Press.

Belsey, Catherine and Moore, Jane (eds) (1997) The Feminist Reader: Essays in Gender and the Politics of Literary Criticism. $2^{\text {nd }}$ ed. Malden MA, Blackwell.

Cixous, Helene (1997) 'Sorties: out and out: attacks/ways out/forays', in Belsey and Moore, pp.91-103.

Dworkin, Andrea (1974) Woman Hating. New York, E.P. Dutton.

Fine, Anne (1996) The Tulip Touch. London, Penguin.

Gleitzman, Morris (2001) Personal communication at his lecture 'Secrets of a best-selling author' Canberra. 11 August.

Hollindale, Peter (1988) 'ldeology and the cliildren's book', Signal 55: 3-22; reprinted in Peter Hunt (ed) (1992) Literature for Children: Contemporary Criticism. London and New York, Routledge, pp.18-40.
Lanagan, Margo (1996) Touching Earth Lightly. St Leonards NSW, Allen \& Unwin.

Moi, Toril (1997) 'Feminist, female, feminine', in Belsey and Moore, pp.104-116.

Nodelman, Perry (1988) 'Literary theory and children's literature: children's literature as women's writing', Children's Literature Association Quarterty 13, 1, Spring: 31-34.

Stephens, John (1992) Language and Ideology in Children's Fiction. New York and London, Longman.

Voigt, Cynthia (1994) When She Hollers. New York, Scholastic.

Walker, Sarah (1999) The Year of Freaking Out. Sydney, Pan Macmillan.

Zipes, Jack (1991) [1983] Fairy Tales and the Art of Subversion: The Classical Genre for Children and the Process of Civilisation. New York, Routledge [Heinemann Education].

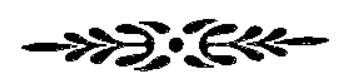

\section{BIOGRAPHICAL NOTE}

Anna Beth McCormack is enrolled in the M.A. (Children's Literature) program at Deakin, after a mixed career in book editing and librarianship. This paper, which won the ACLAR essay prize in 2002, reflects her interest in representations of child abuse in literature for young reader. 


\section{DATA APPENDIX}

- A 1997 Australian study of 710 randomly selected women found that during childhood $20 \%$ had had 'unwanted sexual experiences with an adult that involved at least genital contact'.

- A wider group of $35 \%$ during childhood had had 'some sexual abuse or experience that was unwanted or distressing'.

- These figures were not unlike figures for similar studies in New Zealand and the USA.

Among the $20 \%$ :

- Intercourse had occurred in $10 \%$ of cases and been attempted in another $17 \%$.

- The mean age of first abuse was 10 years; $71 \%$ were aged $<12$ years al the time.

- The duration of multiple abuse was $<1$ year for $57 \%$, $<2$ years for $14 \%,>2$ years for $29 \%$.

- Abusers were usually male (98\%) and usually known to the child; $41 \%$ were relatives.

- Children who grew up without a father were the most likely to have been sexually abused, followed by children with stepfathers and children who grew up with their biological father.

- $52 \%$ had disclosed the abuse; $<10 \%$ had reported to the police, a doctor or a helping agency.

- For $23 \%$ disclosure had stopped the abuse; for $22 \%$ it had not.

(Fleming 1997, p.65-8)

- In any year, Kids Help Line counsellors respond to over 7700 calls concerning sexual abuse, of which $75 \%$ are made by female callers.

- The proportion of callers by age is normally distributed and peaks at ages 13-14.
- Of sexual abuse calls received, $22 \%$ of callers were the victims of current sexual abuse at the time of calling.

(Kids Help Line, 18/9/01)

- 'There is now good evidence that women who report child sexual abuse have increased rates of psychiatric. psychological and social problems in adult life'

- 'There are important questions about the process of disclosure too; some victims have reported that the official responses from welfare, judiciary and medical institutions can be worse that the abuse itself.'

(Romans 1997, p. 59)

\section{DATA APPENDIX REFERENCES}

Fleming, Jillian M. (1997) 'Prevalence of childhood sexual abuse in a community sample of Australian women', Medical Journal of Australia, 166: 65-8.

Kids Help Line (website) http:// www.squirrel.com.au/boystown/ sexabuse.htm

Romans, Sarah E. (1997) 'Childhood sexual abuse: concerns and consequences', Medical Journal of Australia, 166: 59-60. 